\title{
PENERAPAN PENDEKATAN SAINTIFIK MODEL DISCOVERY LEARNING UNTUK MENINGKATKAN HASIL BELAJAR PADA MATERI POTENSI SUMBER DAYA ALAM DAN KEMARITIMAN INDONESIA SISWA KELAS VII SMP DARUSSA'ADAH PUTRI
}

\author{
Nuraini \\ SMP Darussadah Putri Pidie Jaya \\ e-mail : Nuraini101@gmail.com
}

\begin{abstract}
ABSTRAK
Penelitian ini bertujuan untuk mendeskripsikan aktivitas belajar siswa dan hasil belajar Siswa dengan menerapkan Pendekatan Saintifik Model Discovery Learning pada materi Potensi Sumber Daya Alam dan Kemaritiman. Penelitian tindakan kelas ini dilaksanakan dalam dua siklus. Setiap siklus terdiri dari empat tahapan yaitu perencanaan, pelaksanaan tindakan, pengamatan, dan refleksi. Subjek dalam penelitian ini yaitu siswa kelas VII SMP Darussa'adah Putri tahun pelajaran 2015/2016, dengan jumlah 24 siswa yang terdiri dari 7 siswa perempuan dan 17 siswa laki-laki. Teknik pengumpulan data yang digunakan yaitu teknik tes dan non tes. Analisis data dilakukan dengan analisis data kuantitatif rata-rata nilai tes formatif siklus I sebesar 61,46 meningkat pada siklus II menjadi 77,50. Ketuntasan belajar klasikal pada siklus I sebesar 38\% meningkat pada siklus II menjadi 92\%. Dengan demikian, dapat disimpulkan bahwa penerapan model pembelajaran saintifik model discovery learning dapat meningkatkan hasil belajar siswa materi Potensi Sumber daya Alam dan Kemaritiman Indonesia pada siswa kelas VII SMP Darussa'adah Putri. Oleh karena itu, guru disarankan untuk menerapkan model saintifik model discovery learning dalam pembelajaran IPS atau pelajaran lain.
\end{abstract}

Kata Kunci: Saintifik Model Discovery Learning, Hasil Belajar

\begin{abstract}
This study aims to describe student learning activities and student learning outcomes by applying the Scientific Approach to the Discovery Learning Model in the material of the Potential of Natural Resources and Maritime. This classroom action research was carried out in two cycles. Each cycle consists of four stages, namely planning, implementing actions, observing, and reflecting. The subjects in this study were seventh grade students of Darussa'adah Putri Middle School in the 2015/2016 academic year, with 24 students consisting of 7 female students and 17 male students. Data collection techniques used are test and non-test techniques. Data analysis was performed by quantitative data analysis the average formative test value of the first cycle of 61.46 increased in the second cycle to 77.50. Classical learning completeness in the first cycle of $38 \%$ increased in the second cycle to $92 \%$. Thus, it can be concluded that the application of the scientific learning model discovery learning model can improve student learning outcomes in the material of the Potential of Natural Resources and Indonesian Maritime in class VII students of Darussa'adah Putri Middle School. Therefore, teachers are advised to apply the scientific model of discovery learning models in social studies learning or other lessons.
\end{abstract}

Keywords: Scientific Discovery Learning Model, Learning Outcomes

\section{LATAR BELAKANG}

Pada jenjang Sekolah Menengah

Pertama (SMP), mata pelajaran sejarah diberikan sebagai bagian integral dari mata pelajaran Ilmu Pengetahuan Sosial (IPS). Hal ini disebabkan karena pada jenjang 
SMP, mata pelajaran sejarahmerupakan salah satu mata pelajaran terpadu yang terdiri dari beberapa cabang ilmu, yaitu sosiologi, ekonomi, geografi dan IPS.

Proses belajar-mengajar yang baik adalah proses terciptanya interaksi guru dan peserta didik. Proses interaksi dapat terjadi bila guru mampu mendorong siswa agar terdorong oleh keinginanya sendiri guna menerapkan dan mengamalkan materi yang disampaikan guru.

Selama ini dalam pembelajaran guru menjelaskan materi masih banyak mengunakan ceramah, hal ini membuat siswa bersifat pasif dan berperan sebagai pendengar.

Pendekatan scientific dalam pembelajaran sebagaimana dimaksud meliputi mengamati, menanya, menalar, mencoba, membentuk jejaring untuk semua mata pelajaran. Permendikbud nomor 65 tentang Standar Proses Pendidikan Dasar dan Menengah telah mengisyaratkan tentang perlunya proses pembelajaran yang dipandu dengan kaidah-kaidah pendekatan saintifik/ilmiah pendekatan scientific.

Pembelajaran discovery learning merupakan suatu rangkaian kegiatan pembelajaran yang melibatkan secara maksimal seluruh kemampuan peserta didik untuk mencari dan mnyelidiki secara sistematis, kritis, dan logis sehingga mereka dapat menemukan sendiri pengetahuan, sikap dan keterampilan sebagai wujud adanya perubahan perilaku

Penulis memilih SMP Darussa'adah Putri sebagai objek penelitian di karenakan SMP Darussa'adah Putri merupakan salah satu sekolah yang tetap menggunakan Kurikulum 2013. Sehingga dalam pembelajarannya pun disesuaikan dengan Kurikulum 2013. Namun dalam pelaksanaan pendekatan saintifik ini belum sepenuhnya di kolaborasikan dengan model pembelajaran lain. Maka peneliti akan meneliti dengan menambahkan pendekatan model discovery learning dalam pendekatan saintifik, agar menjadikan peserta didik diharapkan lebih aktif dalam proses belajar- mengajar. Berdasarkan uraian tersebut maka penulis tertarik mengadakan penelitian dengan judul "Penerapan Model Saintifik model Discovery Learning untuk Meningkatkan Hasil Belajar pada Materi Potensi Sumber daya Alam dan Kemaritiman Indonesia Siswa Kelas VII SMP Darussa'adah Putri”.

\section{KERANGKA TEORITIS \\ Pengertian Model Saintifik}

Pendekatan saintifik/ilmiah merupaka $\mathrm{n}$ proses pembelajaran yang menggunakan proses berpikir ilmiah. Pendekatan ilmiah dapat dijadikan sebagai jembatan untuk perkembangan dan pengembangan sikap, keterampilan, dan pengetahuan peserta didik. Kemendikbud (2013) memberikan konsepsi bahwa pendekatan ilmiah (scientific approach) dalam pembelajaran $\mathrm{m}$ encakup komponen: mengamati,menanya, mencoba, mengolah, menyajikan, menyimpulkan dan mencipta.

Penerapan pendekatan saintifik dalam pembelajaran melibatkan keterampil an proses seperti mengamati, mengklasifikasikan, mengukur, meramalkan, menjelaskan, dan menyimpulkan. Dalam melaksanakanya proses tersebut, bantuan guru diperlukan. Akan tetapi bantuan guru tersebut harus semakin berkurang dengan semakin bertambah dewasanya siswa atau semakin tingginya kelas siswa (Daryanto, 2013:51)

Pembelajaran dengan pendekatan saintifik memiliki karakteristik sebagai berikut.

1. Berpusat pada siswa.

2. Melibatkan keterampilan proses sains dalam mengkonstruksi konsep, hukum atau prinsip.

3. Melibatkan proses-proses kognitif yang potensial dalam merangsang perkembangan intelek, khususnya keterampilan berpikir tingkat tinggi siswa.

4. Dapat mengembangkan karakter siswa. 


\section{Pengertian Discovery learning}

Oemar Hamalik dalam ilahi (2012:

29) discovery adalah proses pembelajaran yang menitikberatkan pada mental intelektual para anak didik dalam memecahkan berbagai persoalan yang dihadapi, sehingga menemukan suatu konsep atau generalisasi yang dapat diterapkan di lapangan. Strategi pembelajaran yang dikembangkan pertama kali oleh Burner ini menitikberatkan pada kemapuan anak didik dalam menemukan sesuatu melalui proses inquiry (penelitian) secara terstruktur dan terorganisir dengan baik. Discovery strategy merupakan strategi pembelajaran yang menekankan pengalaman langsung di lapangan, tanpa harus selalu bergantung pada teori-teori pembelajaran yang ada dalam pedoman buku pelajaran (Mulyasa: 2015:10), dengan kata lain proses pembelajaran lebih diutamakan dari pada hanya sekedar hasil akhir yang terlihat, proses pembelajaran discovery tidak menekankan agar peserta didik sepenuhnya menguasai materi melainkan lebih menekankan pada pemahaman mereka. Yang dimaksud proses mental dimana siswa mampu mengasimilasi suatu konsep atau prinsip yang dimaksud proses mental tersebut yaitu mengamati, mencerna, mengerti, menggolong-golongkan, membuat dugaan, menjelaskan, mengukur, membuat kesimpulan

Fungsi pembelajaran dengan discovery learning yaitu sebagai berikut.

a. Membangun komitmen dikalangan peserta didik untuk belajar, yang diwujudkan dengan ketertiban, kesungguhan dan loyalitas terhadap mencari dan menemukan suatu dalam proses pembelajaran.

b. Membangun sikap, kreatif, dan inovatif dalam proses pembelajaran dalam rangka mencapai tujuan pembelajran.

c. Membangun sikap percaya diri (Self Confidence) dan terbuka (Openess) terhadap hasil temuanya (Suhana dan Hanafi, 2009: 78).

\section{Pendekatan Saintifik Model Discovery Leaning}

Pendekatan saintifik mengajarkan agar peserta didik aktif dan menemukan pemecahan suatu masalah dengan mengunakan pendekatan saintifik. Yaitu pelajaran yang berpusat pada peserta didik agar peserta didik berusaha menemukan sendiri beragam informasi yang dibutuhkan.

Sehingga dalam proses pembelajaranya guru tidak sendirian aktif, tetapi peserta didik didorong agar mampu menemukan informasi-informasi lewat proses mengamati, menanya, menalar, mencoba, menginformasikan atau menyajikan. Untuk mendukung proses belajar menggunakan pendekatan saintifik perlu adanya pembelajaran berbasis penyikapan atau penelitian (discovery/ inquiry learning).

Langkah-langkah pendekatan saintifik model discovery learning, Mengamati melalui stimulus siswa diajak untuk mengamati dan menanya, tahap problem statement siswa diajak menanya dan mengumpulkan informasi, tahap data collection siswa diajak untuk mencoba dan mengamati, tahap data processing siswa diajak untuk menalar dan menanya dan tahap terakhir verification siswa diajak menalar, dan mengkomunikasikan.

Dari uraian diatas dapat penulis simpulkan bahwa Pendekatan Saintifik Model Discovery Learning merupakan kegiatan pembelajaran yang berpusat kepada siswa dengan mendapatkan informasi melaui kegiatan kegiatan penelitian.

\section{Belajar dan Pembelajaran}

Belajar merupakan proses pokok dalam kegiatan mengajar di sekolah. (Hamalik, 2007: 106). Pendapat terakhir berpendapat bahwa belajar merupakan suatu proses, dan bukan hasil yang hendak dicapai semata, proses itu sendiri berlangsung melalui serangkaian pengalaman, sehingga terjadi 
modifikasi pada tingkah laku yang telah dimilikinya sebelumnya.

Jadi berdasarkan proses akan tercapai tujuan. Belajar menurut teori behavioristik diartikan sebagai proses perubahan tingkah laku. Perubahan tersebut disebabkan oleh seringnya interaksi antara stimulasi dan respon, inti belajar adalah kemampuan seseorang melakukan respon terhadap stimulus yang datang kepada dirinya (Aqib, 2013: 66)

Menurut Slameto (2010: 54), faktorfaktor yang mempengaruhi belajar banyak jenisnya tetapi dapat digolongkan menjadi dua golongan menjadi faktor intern dan faktor ekstern. Faktor intern adalah faktor yang ada dalam diri individu yang sedang belajar, sedang faktor ekstern adalah faktor yang ada di luar individu.

a. Faktor Intern

Di dalam membicarakan faktor intern ini, akan dibahas menjadi tiga faktor, yaitu:

1) Faktor Jasmaniah, terdiri dari faktor kesehatan dan cacat tubuh

2) Faktor Psikologis, terdiri dari intelegensi, perhatian, minat, bakat, motivasi, kematangan, kesiapan.

3) Faktor Kelelahan, dapat dibedakan menjadi dua macam yaitu kelelahan jasmani dan kelelahan rohani (bersifat psikis).

\section{b. Faktor Ekstern}

Faktor ekstern yang berpengaruh terhadap belajar, dikelompokkan menjadi 3 faktor, yaitu: faktor keluarga, faktor sekolah dan faktor masyarakat.

1) Faktor Keluarga, terdiri dari cara orang tua mendidik, relasi antar anggota keluarga, suasana rumah, keadaan ekonomi keluarga, perhatian orang tua, latar belakang kebudayaan.

2) Faktor Sekolah, terdiri dari metode mengajar, kurikulum, relasi guru dengan siswa, relasi siswa dengan siswa, disiplin sekolah, alat pelajaran, waktu sekolah, standar pelajaran di atas ukuran, keadaan gedung, metode belajar, tugas rumah.
3) Faktor Masyarakat, terdiri dari kegiatan siswa dalam masyarakat, teman bergaul, bentuk kehidupan masyarakat.

\section{METODOLOGI PENELITIAN Waktu dan Tempat Penelitian}

Waktu penelitian dilaksanakan pada semester I, tahun pelajaran 2015/2016 atau bulan September s.d November 2015 di SMP Darussa'adah Putri Kecamatan Panteraja Kabupaten Pidie Jaya.

\section{Pendekatan penelitian}

Pada proses penelitian hendaknya dapat menentukan suatu metode penelitian yang akan digunakan,hal ini berdasarkan pada suatu pemahaman bahwa metode penelitian dapat dijadikan suatu cara atau langkah untuk memperoleh suatu data, meganalisis data, sehingga pada akhirnya akan mendapatkan hasil dari sasaran serta tujuan penelitian yang dilakukan. Dalam mencapai tujuan yang diinginkan pada penelitian yang dilakukan maka penting sekali bagi peneliti untuk memilih metode penelitian yang tepat sebagai metode penelitian yang akan dicapai.

Penggunaan metode penelitian sangat tergantung kepada permasalahan yang akan dibahas, hal ini dapat diartikan bahwa penggunaan suatu metode penelitian dapat dilihat dari segi efektifitas, efesiensi serta relevansinya metode penelitian tersebut dengan permasalahan pada sebuah penelitian yang dilakukan. Metode penelitian dikatakan efektif apabila selama pelaksanaan penelitian dapat terlihat adanya suatu perubahan positif kearah tujuan yang diharapkan, sedangkan apabila dalam pelaksanaan penelitian penggunaan waktu, fasilitas, biaya, dan tenaga dapat terlaksana dengan sehemat mungkin akan tetapi tujuan penelitian tetap tercapai maka metode tersebut dikatakan efisien dalam sebuah penelitian. Selanjutnya penelitian dapat dikatakan relevan apabila penelitian tersebut berjalan dengan lancer serta dapat menghasilkan hasil sesuai dengan 
tujuan penelitian serta adanya kesesuaian antara waktu penggunaan hasil pengolahan dengan tujuan yang akan dicapai pada suatu penelitian tidak terjadi penyimpangan.

Pendekatan dalam penelitian ini menggunakan pendekatan penelitian kualitatif karena penelitian ini bersifat deskriptif dan naturalistik. Penelitian ini bersifat deskriptif karena hanya mendeskripsikan tentang hasil peningkatan pembelajaran IPS Materi untuk meningkatkan hasil belajar pada materi Potensi Sumber Daya Alam dan kemaritiman Indonesia Melalui Penerapan Saintifik Model Discovery Learning Pada siswa kelas siswa kelas VII SMP Darussa'adah Putri. Pendekatan kualitatif bersifat naturalistik karena penelitian ini memang terjadi secara alamiah, apa adanya, dalam situasi normal yang tidak memanipulasi keadaan dan kondisinya. Kedua sifat penelitian kualitatif tersebut menuntut keterlibatan peneliti secara langsung (partisipasi aktif) baik pada awal pembelajaran maupun yang terjadi setelah diterapkannya tindakan di lapangan.

\section{Jenis Penelitian}

Jenis penelitian ini adalah jenis Penelitian Tindakan Kelas (Class Action Research) karena penelitian dilakukan oleh Gurudi sekolah nya sendiri dengan jalan merancang, melaksanakan, dan merefleksikan tindakan secara kolaboratif dan partisipatif dengan tujuan untuk memperbaiki kinerja Guru sehingga hasil belajar siswa dapat meningkat. Penelitian Tindakan Kelas yang digunakan dalam penelitian ini adalah Model Kurt Lewin yang terdiri dari empat komponen, yaitu: a) Perencanaan (Planning); b) Tindakan (Acting; c) Pengamatan (Observing; dan d) Refleksi (Refecting)

\section{Rancangan Penelitian}

Rancangan model penelitian yang dipakai dalam penelitian ini adalah menggunakan Penelitian Tindakan Kelas model spiral atau siklus menurut Arikunto
(2009:16), bertujuan apabila dalam pelaksanaan tindakan ditemukan adanya kekurangan, maka dapat dilakukan perbaikan yang dilanjutkan pada siklus berikutnya sampai target diinginkan tercapai. Dalam setiap siklus terdiri dari empat tahapan yaitu perencanaan, pelaksanaan tindakan, observasi, dan refleksi Rancangan Penelitian sebagai berikut:

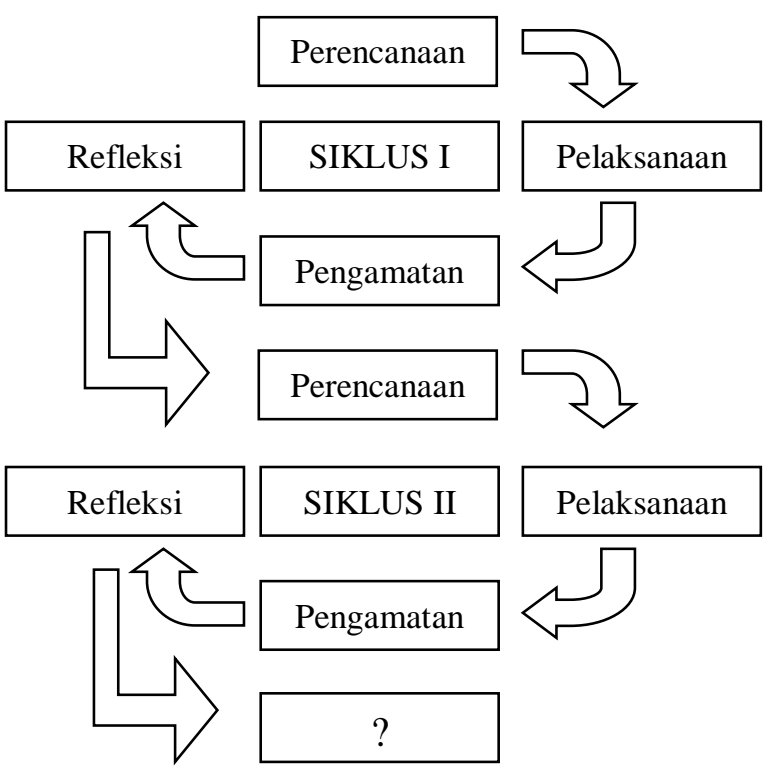

Menurut Arikunto, (2009:17) langkahlangkah penelitian dilaksanakan dalam tahapan

\section{Perencanaan}

Didalam tahap perencanaan, peneliti menentukan fokus peristiwa yang perlu mendapatkan perhatian khusus untuk diamati, kemudian dilanjutkan membuat sebuah instrumen pengamatan untuk membantu peneliti mengambil data dalam merekam fakta yang terjadi selama tindakan

\section{Pelaksanaan Tindakan}

Pelaksanaan tindakan yakni implementasi atau penerapan isi rancangan di dalam kancah, yaitu mengenakan tindakan di kelas. Dalam tahap pelaksanaan tindakan guru melaksanakan pembelajaran dengan menggunakan Penerapan Saintifik Model Discovery Learning Pada siswa kelas siswa kelas VII SMP Darussa'adah 
Putri sesuai materi akan diajarkan. Kolaborator berperan untuk melakukan pengamatan dalam pelaksanaan tindakan atau kegiatan pembelajaran

\section{Observasi}

Observasi atau pengamatan yaitu pelaksanaan pengamatan oleh pengamat yang dilakukan secara teliti dan dan melakukan pencatatan secara sistematis Pelaksanaan observasi atau pengamatan bersamaan dengan pelaksanaan tindakan atau kegiatan pembelajaran. Dalam tahap ini kolaborator melakukan pengamatan dan mendokumentasikan keterampilan guru, aktivitas siswa, hasil belajar. Pengamatan dilakukan dengan menggunakan pedoman observasi.

\section{Refleksi}

Refleksi adalah perenungan kembali atas apa yang telah dilakukan untuk dijadikan cermin (pedoman) perbaikan bagi aktivitas selanjutnya (Poerwanti, 2009:5.45). Dalam tahap ini peneliti dan kolaborator mendiskusikan hasil pengamatan selama pelaksanaan tindakan berlangsung. Kekurangan yang ditemui dalam siklus sebelumnya digunakan sebagai dasar penyusunan rencana pelaksaan tindakan pada siklus selanjutnya. Dengan demikian maka siklus selanjutnya akan berjalan lebih baik dari pada siklus sebelumnya

\section{Subyek Penelitian}

Subjek dalam penelitian ini adalah Guru Bidang Study IPS SMP Darussa'adah Putri Panteraja dan siswa kelas VII SMP Darussa'adah Putri Kecamatan Panteraja Kabupaten Pidie Jaya sebanyak 24 orang, dengan rincian putri sebanyak 13 orang dan putra 11 orang.

\section{Instrumen Penelitian}

Instrumen yang digunakan dalam penelitian ini terdiri dari
1. Observasi

2. Catatan Harian (Field Note)

3. Test

4. Dokumentasi

\section{Teknik Pengumpulan Data}

Teknik pengumpulan data yang dilakukan dalam penelitian ini meliputi teknik tes dan teknik non tes, sebagai berikut:

1. Tes

Teknik tes adalah seperangkat tugas yang harus dikerjakan atau sejumlah pertanyaan yang harus dijawab oleh peserta didik untuk mengukur tingkat pemahaman dan penguasaannya terhadap cakupan materi yang dipersyaratkan dan sesuai dengan tujuan pengajaran tertentu (Poerwanti, 2008:1.5).

Dalam penelitian ini teknik tes berupa tes tertulis yaitu dengan menggunakan alat pengumpulan data berupa soal evaluasi yang diberikan kepada siswa pada setiap akhir pertemuan dalam setiap siklus. Tes dalam penelitian ini digunakan untuk mengukur atau memberi angka terhadap proses pembelajaran ataupun pekerjaan siswa sebagai hasil belajar yang merupakan cerminan tingkat penguasaan terhadap materi yang diajarkan.

Nontes

Teknik nontes adalah suatu alat penilaian yang digunakan untuk mendapatkan informasi tertentu tentang keadaan peserta tes tanpa menggunakan tes (Hamdani, 2011:316). Dalam penelitian ini, teknik nontes dilakukan dengan observasi, dokumentasi, catatan lapangan.

a. Observasi.

Teknik pengumpulan data lewat megnamati setiap kejadian berlangsung serta mencatatnya dengan alat observasi sesuai hal-hal diamati atau diteliti (Sanjaya, 2010:86). Observasi dalam penelitian ini digunakan untuk mengamati aktivitas siswa dan keterampilan guru dalam pembelajaran IPS dengan menggunakan pendekatan Model Cooperative Learning Tipe Student Team Achievment Division (STAD) selama 
pelaksanaan tindakan dalam penelitian berlangsung.

b. Teknik Dokumentasi

Dokumentasi berasal dari kata dokumen, yang artinya barang-barang tertulis. Dalam melaksanakan metode dokumentasi, peneliti menyelidiki bendabenda tertulis seperti buku-buku, majalah, dokumenen, peraturan-peraturan, notulen rapat, catatan harian, dan sebagainya (Novianti, 2012). Dalam penelitian ini metode dokumen digunakan untuk memperoleh data nama-nama siswa subyek penelitian dan nilai atau hasil evaluasi siswa yang digunakan untuk mengetahui besarnya peningkatan hasil belajar siswa.

\section{HASIL PENELITIAN DAN PEMBAHASAN \\ Kondisi Pra Siklus}

Kondisi pra siklus (data awal peneitian) merupakan kondisi dimana belum diadakannya tindakan perbaikan pembelajaran. Data pra siklus yang diperoleh merupakan data yang diambil ulangan harian di kelas VII SMP Darussa'adah Putri Kecamatan Panteraja Kabupaten Pidie Jaya, baik berupa catatan lapangan mengenai pembelajaran IPS, data hasil belajar siswa, maupun data dokumen dari guru kelas VII yang berhubungan dengan pembelajaran IPS di kelas. Data tersebut kemudian dianalisis bersama dengan guru kolaborator, dan ditemukan suatu permasalahan di dalam pembelajaran IPS yaitu kualitas pembelajaran IPS masih rendah. Faktor penyebabnya yaitu guru belum menggunakan model pembelajaran inovatif, materi yang dipelajari banyak sehingga siswa cenderung kurang aktif dan kurang antusias dalam mengikuti pembelajaran serta kurangnya kerjasama siswa dalam belajar kelompok. Selain itu lingkungan kurang mendukung, media belajar kurang menarik sehingga siswa kurang termotivasi belajar. Hal-hal tersebut berpengaruh terhadap proses dan hasil belajar IPS siswa kelas VII SMP Darussa'adah Putri Kecamatan Panteraja Kabupaten Pidie jaya

Berdasarkan refleksi awal antara peneliti dengan kolaborator mengenai pembelajaran IPS di SMP Darussa'adah
Putri didapatkan data kuantitatif berupa data pra siklus yang menunjukkan bahwa sebagian besar siswa belum mencapai nilai kriteria ketuntasan minimal (KKM) yang ditetapkan sekolah yaitu 65. Hasil belajar mata pelajaran IPS hanya 16\% (3 dari 19 siswa) mendapat nilai $65 \mathrm{ke}$ atas atau tuntas belajar, sedangkan 16 siswa $(84 \%)$ belum tuntas. Nilai dan rata-rata kelas 56,05. Berikut Hasil belajar pada kondisi awal dapat diketahui melalui tabel di bawah ini;

Tabel .1 Perolehan Data Hasil Belajar Pra Siklus

\begin{tabular}{|c|l|c|c|c|}
\hline No & $\begin{array}{c}\text { Hasil Tes } \\
\text { akhir }\end{array}$ & Jml & $\%$ & $\begin{array}{c}\text { Rata- } \\
\text { Rata }\end{array}$ \\
\hline 1. & $\begin{array}{l}\text { Siswa yang } \\
\text { tuntas }\end{array}$ & 7 & $29 \%$ & 58,13 \\
\hline 2 & $\begin{array}{l}\text { Siswa yang } \\
\text { tidak tuntas }\end{array}$ & 17 & $71 \%$ & \\
\hline
\end{tabular}

\section{Siklus I}

Sebelum dibuat rencana tindakan maka diadakan identifikasi siswa sebagai subyek penelitian. Berdasarkan informasi dan dokumen diperoleh sebanyak 15 siswa dari 24 siswa, masih banyak dibawah ratarata dalam mata pelajarn IPS secara konkrit kerena dalam pembelajaran IPS menggunakan metode ekspositori/ceramah. Sehingga guru perlu menerapkan metode Saintifik model discovery learning agar siswa dapat memahami konsep IPS dengan konkrit. Hasil kompetensi belajar siswa sebelum penerapan metode Saintifik model discovery learning dapat dilihat pada tabel berikut.

Tabe.2 Perolehan Data Hasil Belajar Siklus I

\begin{tabular}{|c|l|c|c|c|c|}
\hline No & $\begin{array}{c}\text { Hasil } \\
\text { Tes } \\
\text { akhir }\end{array}$ & $\begin{array}{c}\text { Rentang } \\
\text { Nilai }\end{array}$ & Jml & $\%$ & $\begin{array}{c}\text { Rata- } \\
\text { Rata }\end{array}$ \\
\hline 1. & $\begin{array}{l}\text { Siswa } \\
\text { yang } \\
\text { tuntas }\end{array}$ & $65-100$ & 9 & $\begin{array}{c}38 \\
\%\end{array}$ & \\
\cline { 2 - 3 } 2. & $\begin{array}{l}\text { Siswa } \\
\text { yang } \\
\text { tidak } \\
\text { tuntas }\end{array}$ & $40-64$ & 15 & $\begin{array}{c}62 \\
\%\end{array}$ & \\
\hline \multicolumn{2}{|c|}{ Jumlah } & & 24 & 100 & \\
\hline
\end{tabular}


Kegiatan-kegiatan yang akan dilaksanakan pada tahap ini adalah: (1) Menyiapkan rencana pembelajaran. (2) Menyiapkan lembar pengamatan aktivitas belajar siswa dan performansi guru. (3) Menyiapkan alat peraga, media pembelajaran, dan lembar kegiatan siswa. (4) Melaksanakan kegiatan awal pembelajaran, di antaranya: a) Menyiapkan kesiapan kelas; b) Berdoa; c) Presensi; d) Menyampaikan tujuan pembelajaran; e) Memberikan motivasi. (5) Guru menumbuhkan minat siswa yang berkaitan dengan submateri Potensi Sumber daya Alam dan Kemaritiman Indonesia melalui tanya jawab (komponen saintifik model discovery learning: tumbuhkan) (6) Guru memberikan pengalaman nyata berkaitan dengan sub materi Potensi Sumber daya Alam dan Kemaritiman Indonesia pada siswa (komponen saintifik model discovery learning: alami) (7) Guru menyampaikan materi tentang pengertian energi, sumber Lingkungan Hidup yang terdapat di lingkungan sekitar dan macam-macam bunyi berdasarkan frekuensinya pada siswa di pertemuan 1 dan menyampaikan materi perambatan bunyi di pertemuan 2 (komponen saintifik model discovery learning: namai) (8) Guru membagi siswa menjadi kelompok kecil, yaitu setiap kelompok terdiri dari 6 atau 7 siswa. Pembentukkan kelompok bertujuan sebagai sarana interaksi sosial antar siswa. (9) Guru memberikan bimbingan dan bantuan kepada siswa yang mengalami kesulitan belajar. (10) Setiap kelompok memaparkan hasil pekerjaan. 11) Guru bersama siswa mengulangi submateri Potensi Sumber daya Alam dan Kemaritiman Indonesia yang telah dipelajari (komponen saintifik model discovery learning: (12) Guru memberikan penghargaan atau reward berupa gambar senyum bagi siswa atau kelompok yang berhasil menjawab pertanyaan dengan benar a. Tahap Observasi

Peneliti mengamati siswa pada waktu pembelajaran. Apakah dengan melakukan penerapan metode Saintifik model discovery learning dapat membantu siswa untuk memahami konsep Potensi Sumber daya Alam dan Kemaritiman Indonesia. Berdasarkan observasi menunjukkan bahwa dengan metode Saintifik model discovery learning siswa lebih tertarik dan senang mengikuti kegiatan pembelajaran IPS, meskipun masih terlihat ada beberapa siswa yang kurang antusias. Guru membimbing siswa, mengadakan evaluasi dan mengolah data yang diperoleh, mengidentifikasi dan menginterpretasi data untuk menentukan tingkat pencapaian tindakan.

b. Tahap Reflesi

Mengadakan refleksi untuk tindakan yang telah dilaksanakan apakah berhasil dan efektif dalam meningkatkan prestasi pembelajaran dengan menggunakan metode saintifik model discovery learning. Guru selaku peneliti perlu kreatif dalam penggunaan media pembelajaran sesuai dengan konsep. Guru mengamati dan mengevaluasi siswa dengan memberikan pertanyaan-pertanyaan lisan seputar indikator pembelajaran yang ingin dicapai. Kemudian guru memberikan penghargaan kepada kelompok yang bekerja bagus (acuan guru adalah hasil pengamatan aktifitas siswa dalam keterampilan kooperatif) dan dilanjutkan dengan mengadakan response/kuis secara tertulis untuk mengetahui sejauh mana kompetensi yang diharapkan dapat dikuasai siswa. Nilai tersebut dicatat guru dan peneliti yang dipakai sebagai dasar analisis perkembangan kompetensi IPS siswa dari setiap pertemuan ke pertemuan berikutnya.

\section{Siklus II}

Melanjutkan tindakan sebelumnya melalui pelaksanaan proses belajar mengajar dengan menggunakan Metode saintifik model discovery learning untuk memahami konsep Potensi Sumber daya Alam dan Kemaritiman Indonesia. Guru sebagai peneliti mencatat perkembangan kemampuan siswa dalam pembelajaran IPS pada setiap pertemuan. 
Melanjutkan tindakan sebelumnya melalui pelaksanaan proses belajar mengajar dengan menggunakan Metode saintifik model discovery learning untuk memahami konsep Potensi Sumber daya Alam dan Kemaritiman Indonesia. Guru sebagai peneliti mencatat perkembangan kemampuan siswa dalam pembelajaran IPS pada setiap pertemuan.

a. Tahap Pelaksanaan Tindakan

Melaksanakan pembelajaran menggunakan metode Saintifik model discovery learning, guru menanamkan konsep Potensi Sumber daya Alam dan Kemaritiman Indonesia dengan penyajian materi dengan demonstrasi menggunakan media gambar, agar siswa lebih mudah memahami konsep dan pembelajaran lebih bermakna. Dalam melaksanakan pembelajaran siswa selalu dibimbing dan dipantau oleh guru sampai seluruh materi dapat dipahami siswa.

b. Tahap Observasi

Peneliti mengamati siswa pada waktu pembelajaran. Apakah dengan melakukan penerapan metode Saintifik model discovery learning dapat membantu siswa untuk memahami konsep organ pencernaan manusia dan hubungannya dengan makanan dan kesehatan. Berdasarkan observasi setelah guru memodifikasi metode saintifik model discovery learning dalam praktek IPS dengan penyampaian materi menggunakan media audiovisual berupa powerpoint menunjukkan bahwa siswa lebih tertarik, senang dan antusias mengikuti kegiatan pembelajaran IPS. Guru membimbing siswa, mengadakan evaluasi dan mengolah data yang diperoleh, mengidentifikasi dan menginterpretasi data untuk menentukan tingkat pencapaian tindakan.

c. Tahap Refleksi

Mengadakan refleksi untuk tindakan yang telah dilaksanakan apakah berhasil dan efektif dalam meningkatkan prestasi pembelajaran dengan menggunakan metode saintifik model discovery learning. Guru mengamati dan mengevaluasi siswa dengan memberikan pertanyaan-pertanyaan lisan seputar indikator pembelajaran yang ingin dicapai. Kemudian guru memberikan penghargaan kepada kelompok yang bekerja bagus (acuan guru adalah hasil pengamatan aktivitas siswa dalam keterampilan kooperatif: kelompok ahli dan kelompok asal) dan dilanjutkan dengan mengadakan response/kuis secara tertulis untuk mengetahui sejauh mana kompetensi yang diharapkan dapat dikuasai siswa. Nilai tersebut dicatat guru selaku peneliti yang dipakai sebagai dasar analisis perkembangan kompetensi IPS siswa dari setiap pertemuan ke pertemuan berikutnya. Hasil nilai ulangan/kuis siswa pada siklus II lebih baik/sempurna maka guru tidak perlu mengadakan tindakan lagi. Hasil kompetensi IPS sesudah penerapan Metode saintifik model discovery learning pada Siklus II siswa kelas VII dapat dilihat pada tebel berikut:

Tabel 3 Perolehan Data Hasil Belajar Siklus II

\begin{tabular}{|c|l|c|c|c|c|}
\hline No & $\begin{array}{l}\text { Hasil Tes } \\
\text { akhir }\end{array}$ & $\begin{array}{c}\text { Renta } \\
\text { ng } \\
\text { Nilai }\end{array}$ & Jml & \% & $\begin{array}{c}\text { Rata- } \\
\text { Rata }\end{array}$ \\
\hline 1. & $\begin{array}{l}\text { Siswa } \\
\text { yang } \\
\text { tuntas }\end{array}$ & $\begin{array}{c}65- \\
100\end{array}$ & 22 & $\begin{array}{c}92 \\
\%\end{array}$ & \multirow{2}{*}{77,50} \\
\cline { 1 - 3 } 2. & $\begin{array}{l}\text { Siswa } \\
\text { yang } \\
\text { tidak } \\
\text { tuntas }\end{array}$ & $\begin{array}{c}40- \\
64\end{array}$ & 2 & $8 \%$ & \\
\hline \multicolumn{2}{|l}{ Jumlah } & & 24 & 100 & \\
\hline
\end{tabular}

Tindakan yang dilakukan guru pada setiap pertemuan selalu dipantau. Dalam memantau tindakan tersebut, guru menggunakan lembar peneliti dan catatan sebagai alat bantu untuk melihat perkembangan kompetensi belajar IPS. Setelah melakukan dan menyelesaikan tindakan pada setiap putaran/siklus, catatan yang ditemukan guru dari observasi dan tindakan yang dilakukan kemudian guru merefleksikan program pembelajaran dan tindakan yang dilakukan. Dari hasil 
penelitian dan pantauan tersebut dapat dilihat hasil perkembangan kompetensi belajar IPS siswa dalam setiap evaluasi pada akhir pembelajaran seperti tercantum dalam tabel berikut:

Tabel 4 Hasil Analisis Nilai Penguasaan Konsep IPS Pra Siklus, Siklus I dan Siklus II

\begin{tabular}{|c|c|c|c|c|c|c|c|}
\hline \multirow{2}{*}{$\begin{array}{l}\mathbf{N} \\
\mathbf{o}\end{array}$} & \multirow{2}{*}{$\begin{array}{c}\text { Ketu } \\
\mathbf{n} \\
\text { tasan }\end{array}$} & \multicolumn{2}{|c|}{$\begin{array}{c}\text { Pra } \\
\text { Siklus }\end{array}$} & \multirow{2}{*}{$\begin{array}{c}\begin{array}{c}\text { Siklu } \\
\text { S I }\end{array} \\
\text { Jlh }\end{array}$} & \multicolumn{3}{|c|}{$\begin{array}{c}\text { Siklus } \\
\text { II }\end{array}$} \\
\hline & & $\begin{array}{l}\text { Jl } \\
\text { h }\end{array}$ & $\%$ & & $\%$ & $\begin{array}{l}\mathbf{J l} \\
\mathbf{h}\end{array}$ & $\%$ \\
\hline 1 & $\begin{array}{l}\text { Tunta } \\
\text { s }\end{array}$ & 7 & $29 \%$ & 9 & $38 \%$ & 22 & $92 \%$ \\
\hline 2 & $\begin{array}{l}\text { Belu } \\
\mathrm{m} \\
\text { Tunta } \\
\mathrm{s} \\
\end{array}$ & 17 & $71 \%$ & 15 & $63 \%$ & 2 & $8 \%$ \\
\hline \multicolumn{2}{|c|}{ Jumlah } & 24 & $\begin{array}{c}100 \\
\%\end{array}$ & 24 & $\begin{array}{c}100 \\
\%\end{array}$ & 24 & $\begin{array}{c}100 \\
\%\end{array}$ \\
\hline
\end{tabular}

Keberhasilan tersebut merupakan salah satu manfaat pembelajaran saintifik model discovery learning yang dapat diambil yaitu sukses atau hasil belajar yang meningkat (DePorter 2010: 12). Hal tersebut telah dibuktikan dengan adanya peningkatan hasil belajar materi Potensi Sumber daya Alam dan Kemaritiman Indonesia melalui model pembelajaran saintifik model discovery learning pada siswa kelas VII SMP Darussa'adah Putri. Untuk mempermudah pemahaman siswa, maka pembelajaran saintifik model discovery learning memperkenalkan asas utamanya, yaitu bawalah dunia mereka ke dunia kita, dan antarkan dunia kita ke dunia mereka. Maksudnya pengalaman awal siswa dijadikan dasar dalam mengaitkan konsep materi yang akan diajarkan siswa sehingga informasi yang abstrak dapat dikongkritkan.

Pembelajaran saintifik model discovery learning merupakan pembelajaran yang menyangkut keterampilan guru dalam merancang, mengembangkan, dan mengelola sistem pembelajaran sehingga guru mampu menciptakan suasana pembelajaran yang efektif, menggairahkan dan memiliki keterampilan hidup. Pelaksanaan pembelajaran saintifik model discovery learning menimbulkan suasana nyaman, menyenangkan karena perancangan dalam pembelajaran dilakukan dengan sistematis, sehingga peserta didik akan memahami konsep (DePorter 2010: 4). Selain itu, penerapan model pembelajaran saintifik model discovery learning membantu siswa untuk mengaitkan materi pembelajaran dengan pengalaman nyata sehingga membuat materi yang dipelajari lebih mudah dipahami dan lebih tertanam dalam memori siswa, sehingga tidak akan mudah dilupakan dan bermakna. Dampaknya dapat dilihat bahwa hasil belajar siswa pada siklus I dan II meningkat dengan baik.

Analisis dari hasil pengamatan aktivitas belajar dan hasil belajar siswa berupa tes formatif, dapat disimpulkan bahwa aktivitas siswa mempengaruhi nilai hasil belajar siswa. Semakin siswa aktif dalam kegiatan pembelajaran, maka siswa cenderung lebih dapat menangkap dan memahami materi pembelajaran sehinggga nilai hasil belajarnya baik.

\section{KESIMPULAN}

Berdasarkan hasil penelitian maka penulis dapat menyimpulkan sebagai berikut

\section{Siklus I}

1. Hasil dari penerapan metode saintifik model discovery learning pada pembelajaran IPS dapat dilihat dari siklus I siswa dapat meraih kompetensi khususnya dalam penguasaan konsep yang lebih baik sehingga penguasaan konsep rata-rata dari 58,13 naik menjadi 61,46. ini dapat diartikan bahwa pada putaran I secara klasikal tampak hasil dari perolehan nilai kuis menggunakan saintifik model discovery learning adalah cukup baik.

2. Hambatan yang ditemukan pada penerapan saintifik model discovery learning adalah: siswa tidak aktif sepenuhnya dalam melakukan diskusi kelompok baik kelompok ahli maupun 
kelompok asal, siswa belum memanfaatkan waktu secara optimal dan siswa masih malu-malu dalam komunikasi atau mengutarakan pendapat.

3. Cara mengatasi hambatan pada siklus I adalah: guru memberikan motivasi, membimbing, mengarahkan siswa dalam kegiatan pembelajaran, baik secara individual maupun kelompok, guru memberi rambu-rambu tentang batas waktu mulai dari melakukan penyajian materi secara demonstrasi, mengerjakan LKS dan evaluasi.

\section{Siklus II}

Pada siklus II kendala sudah semakin kecil, penerapan metode saintifik model discovery learning sudah berkembang, kegairahan belajar IPS meningkat, dan penguasaan konsep IPS rata-rata kelasnya untuk kelas VII naik menjadi 77,50 sehingga siklus ini diharapkan sebagai siklus pemantapan.

Dari keseluruhan siklus I sampai II yang telah dilakukan dapat disimpulkan sebagai berikut: dengan menggunakan saintifik model discovery learning dapat meningkatkan kompetensi belajar IPS khususnya dalam penguasaan konsep materi Potensi Sumber daya Alam dan Kemaritiman Indonesia untuk siswa kelas VII SMA Kecamatan Panteraja Kabupaten Pidie Jaya, hambatan-hambatan dalam penerapan metode saintifik model discovery learning dapat diatasi dengan penentuan materi dan pembatasan materi. Setiap siklus selalu membawa dampak yang positif ke arah peningkatan penguasaan konsep IPS siswa kelas VII SMP Darussa'adah Putri Kecamatan Panteraja Kabupaten Pidie Jaya, Tahun Pelajaran 2015/2016.

\section{DAFTAR PUSTAKA}

Aqib, Zaenal, dkk. 2009. Penelitian Tindakan Kelas untuk Guru SD, SLB, dan TK. Bandung : Yrama Widya.
Arikunto, Suharsimi. 2012. Dasar-Dasar Evaluasi Pendidikan Edisi 2. Jakarta: PT Bumi Akasar .2010.Prosedur Penelitian. Jakarta: Rineka Cipta

Daryanto. 2015. Pendekatan Pembelajaran Saintifik Kurikulum 2013. Yogyakarta: Gava Media.

Ilahi Muhamad, Takdir. 2011. Pembelajaran Discovery Strategy dan Mental Vacation Skill. Jogjakarta: Diva Press

Kemendikbud (2013), Peraturan Mentri Pendidikan dan Kebudayaan Republik Indonesia Nomor 65 Tahun 2013 Tentang Standar Proses Pendidikan Dasar dan Menengah.

Mulyasa. 2013. Pengembangan dan Implementasi Kurikulum 2013. Bandung: Remaja Rosdakarya

Slameto. 2011:316. Belajar Dan FaktorFaktor Yang Mempengaruhiny a. Jakarta: PT Asdi Mahasatya

Sanjaya, 2010:86.Metoda Statistika. Bandung: Tarsito 